\title{
IMAGE ANALYSIS FOR ASSESSING BROILER BREEDER BEHAVIOR RESPONSE TO THERMAL ENVIRONMENT
}

\author{
IRENILZA DE A. NÄÄS ${ }^{1}$, MARCUS LAGANÁ ${ }^{2}$, MARIO MOLLO NETO ${ }^{3}$, \\ SIMONE CANUTO ${ }^{4}$, DANILO F. PEREIRA ${ }^{5}$
}

\begin{abstract}
The research proposes a methodology for assessing broiler breeder response to changes in rearing thermal environment. The continuous video recording of a flock analyzed may offer compelling evidences of thermal comfort, as well as other indications of welfare. An algorithm for classifying specific broiler breeder behavior was developed. Videos were recorded over three boxes where 30 breeders were reared. The boxes were mounted inside an environmental chamber were ambient temperature varied from cold to hot. Digital images were processed based on the number of pixels, according to their light intensity variation and binary contrast allowing a sequence of behaviors related to welfare. The system used the default of $\mathrm{x}, \mathrm{y}$ coordinates, where $\mathrm{x}$ represents the horizontal distance from the top left of the work area to the point $\mathrm{P}$, and $\mathrm{y}$ is the vertical distance. The video images were observed, and a grid was developed for identifying the area the birds stayed and the time they spent at that place. The sequence was analyzed frame by frame confronting the data with specific adopted thermal neutral rearing standards. The grid mask overlapped the real bird image. The resulting image allows the visualization of clusters, as birds in flock behave in certain patterns. An algorithm indicating the breeder response to thermal environment was developed.
\end{abstract}

KEYWORDS: animal welfare, image processing, clusters analysis.

\section{ANÁLISE DE IMAGEM PARA A AVALIAÇÃO DE FRANGOS DE CORTE DE RESPOSTA AO COMPORTAMENTO CRIADOR AMBIENTE TÉRMICO}

RESUMO: Esta pesquisa propõe uma metodologia para avaliação da resposta de matrizes pesadas a mudanças no ambiente térmico de criação. A gravação contínua em vídeo de um grupo de aves, quando analisada, pode oferecer evidências interessantes de conforto térmico, bem como outras indicações de bem-estar. Um algoritmo foi desenvolvido para classificar o comportamento de matrizes de frangos de corte. Vídeos foram registrados sobre três boxes onde 30 matrizes foram alojadas. Os boxes foram montados dentro de uma câmara climática onde a temperatura ambiente variou de frio para quente. As imagens digitais foram processadas com base no número de pixels, de acordo com sua variação da intensidade de luz do contraste binário, permitindo uma sequência de comportamentos relacionados com o bem-estar. O sistema utilizou o padrão de coordenadas $\mathrm{x}, \mathrm{y}$, em que x representa a distância horizontal a partir da esquerda superior da área de trabalho para o ponto $\mathrm{P}$, e y é a distância vertical. As imagens de vídeo foram observadas e uma grade foi desenvolvida para identificar a área ocupada pelas aves e o tempo que elas ocupavam o lugar. A sequência foi analisada quadro a quadro, confrontando os dados com as normas específicas adoptadas para criação dentro da região termoneutra. A máscara quadriculada foi sobreposta à imagem real da ave. A imagem resultante permite a visualização de aglomerações, de como o bando de aves se comporta sob determinado padrão. Um algoritmo indicando a resposta da matriz ao ambiente térmico foi desenvolvido.

PALAVRAS-CHAVE: bem-estar animal, análise de imagens, análise de aglomerações.

\footnotetext{
${ }^{1}$ Eng $^{\underline{a}}$ Civil, Programa de Engenharia de Produção, UNIP, São Paulo, Brasil.

${ }^{2}$ Engenheiro Agrícola.

${ }^{3}$ Eng $^{\mathrm{o}}$ Eletricista, Programa de Engenharia de Produção, UNIP, São Paulo.

${ }^{4}$ Doutoranda em Engenharia de Produção, UNIP.

${ }^{5}$ Eng $^{\mathrm{o}}$ Agrícola, UNESP - Câmpus de Tupã - SP.

Recebido pelo Conselho Editorial em: 10-11-2011

Aprovado pelo Conselho Editorial em: 29-2-2012
} 


\section{INTRODUCTION}

Computerized tracking of animals has been used for behavioral studies (PEREIRA et al., 2007b; BUIJS et al., 2011), to assess animal welfare (BUIJS et al., 2010), and to estimate their body characteristics (MCCLURE et al., 2003; YANAGI et al., 2011). The fundamentals of the system are that animals react to their environment both spatially and temporally, facilitating quantitative studies on how patterns of normal and odd behavior are structured. A common animal behavior recording and the evaluation process involves a video camera, which records animal behavior in real-time or, eventually in a time-lapse mode, according to the requirements of the study. Using graphic interface, a user can input a piece of animal behavior video data, initiate the annotation process, and the system then tracks multiple animal contours and deduces and summarizes the behaviors.

Current literature presents examples of imaging analysis for distinct application in the animal production field (MORROW-TESCH et al., 1998; SERGEANT et al., 1998; PEREIRA, 2005; MOLLAH et al., 2010). SCHWARTZKOPF-GENSWEIN et al. (1998) quantified behavior related to pain, as the response of steers during branding. MCCLURE et al. (2003) used video image analysis system to predict pork carcass composition in a commercial packing plan. CANNELL et al. (2002) evaluated the ability of a commercial video image analysis system to predict yield grading, in order to improve the accuracy of beef grade assessment. SERGEANT et al. (1998) presented the difficulties of observing broilers at the farm level, mainly due to the size of farms, the number of arrays, the contrast between birds and plan background, and variations in the amount of light. Recent studies use methods of detection dynamic forms and patterns of movement (ZHANG \& GONG (2009) which may solve the detection problems of using a sequence of images of low resolution and not a static background (SERGEANT et al., 1998).

Heat stress directly affects breeders' productivity and, in addition, may expose them to high mortality, and reduce live production performance for various genetic strains (PRIETO \& CAMPO, 2010). Adult female breeders reared in temperature around $24 \pm 5^{\circ} \mathrm{C}$ (so-called thermal neutral zone) tend to produce more and present appropriate welfare status (FRANCO-JIMENEZ et al., 2007).

The objective of this research was to assess broiler breeders' behavior response to changes in the rearing thermal environment by using image analysis.

\section{METHODOLOGY}

\section{Video recording and data processing}

The broiler breeder behavioral experiment took place in a controlled environment chamber. Inside the chamber three boxes were built (1.50 m high, $1.32 \mathrm{~m}$ of length and 2.14 of depth) in which 20 broiler female breeders and 2 male breeders 38-39 weeks old, and from the genetic strain Hybro $\mathrm{PG}^{\circledR}$ were reared. Wood shavings litter was used as bedding. Light program and feeding system were used as in a commercial farm. Surveillance video cameras RGB were placed over the boxes for continuously recording the birds' movements. Data were recorded using a server with two processors Xeon $3.0 \mathrm{GHz}, 1024 \mathrm{Mb}$ Ram and five $\mathrm{HD}$ with $60 \mathrm{~Gb}$ each with storage capacity of $300 \mathrm{~Gb}$. Data were stored using a specific software called FireBird®. The system had three modules; the first is referred to support the recording of data such as ambient temperature, traceability data including electronic ID of the birds, total feed ration consumption, and the video camera continuous recording. The second one recorded and compared the new data with former already stored in the system; and the third generates the historical of data collected in real time.

Another software was developed to process the images from FireBird ${ }^{\circ}$ module one (video recording) with access to suitable filters. For this experiment the video image were processed using the filter Blob Explorer, which enhances bird in contrast to its adjacent area. Behavioral observations were done using two ranges of different controlled temperatures inside the 
environmental chamber a) $\leq 29^{\circ} \mathrm{C}$, and b) $>29^{\circ} \mathrm{C}$ (PRIETO \& CAMPO, 2010). Due to the environmental chamber thermal inertia the registered temperatures with a variation of $1.0{ }^{\circ} \mathrm{C}$ were accepted during the trial. The relative humidity was kept within the range of $65-70 \%$. Using the images recorded by the surveillance cameras over the boxes, behavioral information were extracted related to the birds' reaction to the characteristics of the environment (ambient dry bulb temperature and relative humidity). The analysis used knowledge on selected behaviors that are identified reaction to cold and hot environment (FRANCO-JIMENEZ et al., 2007; PEREIRA et al., 2007 a,b; Table 1). The algorithm processed the captured images, and segmented them using a grid of 33.5 by $20.7 \mathrm{~cm}$ (equivalent to a monitor wide screen 15.4") with approximately $9 \mathrm{~cm}$ by $6.7 \mathrm{~cm}$ of approximately $1 \mathrm{~cm}^{2}$ each (Figure 1).

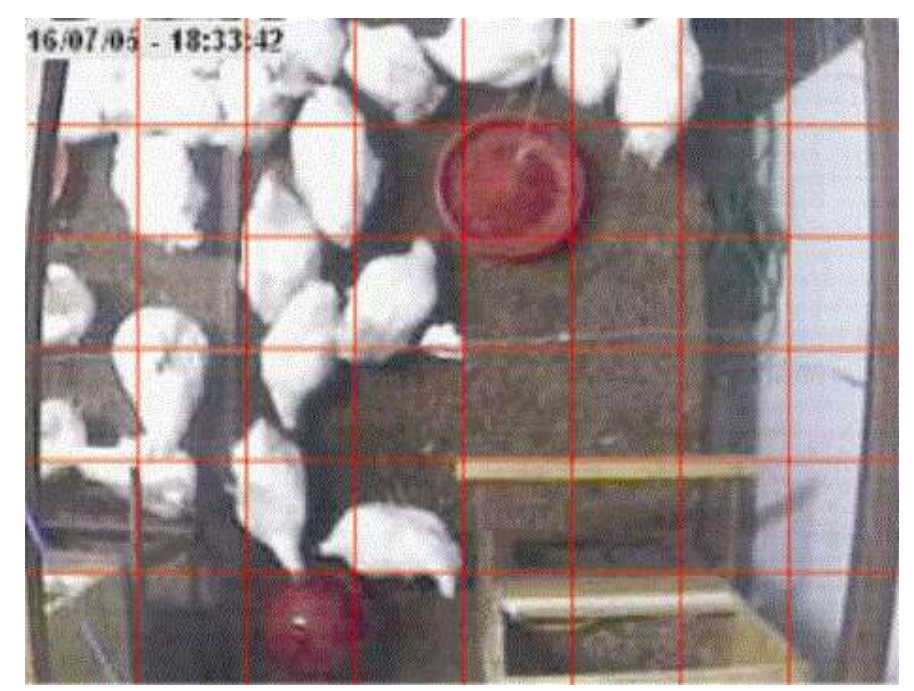

FIGURE 1. The adopted grid overlapping the image, which shows the breeder' occupying the area of the experimental box.

The video footages recorded from PEREIRA (2005) were watched carefully by a trained observer using the appropriate ethogram description (Table 1; PEREIRA et al., 2007 a,b). Two records were made the first was binary, and showed the breeders' positions with relation to the division adopted using the following legend: 1 for the square where there was one or more breeders, and zero where no bird was found. The second one marked the area when a behavior from Table 1 occurred.

TABLE 1. Descriptive ethogram of the experimental observed behaviors.

\begin{tabular}{ll}
\hline Behavior & Description \\
\hline $\begin{array}{l}\text { Opening wings } \\
\text { Stretching }\end{array}$ & When the bird flaps both wings. \\
Threatening & The bird stretches one wing and one leg of the same body hemisphere. \\
Ruffling feathers & One bird stands before another. \\
Foraging & Action of ruffling or shaking all feathers. \\
Pecking & Movement of scratching the litter backwards with its feet and search for food in the litter. \\
Lying down & The bird aggressively pecks any part of the body of another bird. \\
Running & The bird sits or lies down on the litter. \\
At the drinker & Movement of the bird between two points at high speed. \\
Clustering & The bird stays at the drinker not necessarily drinking water. \\
Drinking & Birds get together in a clustered position. \\
Dust bathing & The bird stays at the drinker and ingests water. \\
Preening & Bath performed by the bird using the litter substrate. \\
Mounting & The bird arranges its feathers with the beak inducing the uropigeal gland. \\
Chasing & Male or female birds climbing on the back of another bird. \\
Prostration & One birds run after another aiming at pecking or using another form of aggression. \\
& The bird lies on the litter with open beak half opened wings, and pants aiming at increasing \\
Adapted from PEREIRA et al. (2007a, b).
\end{tabular}




\section{Breeder distribution}

Behavioral data from the video images were observed each 30s and stored on tables using Microsoft Office Excel 2007. Each position in the matrix represented a cell in Excel, and the distinct matrix of the same video was stored one below the other. Adding the value of the same cell ( 1 or 0 ) of a distinct matrix for the same video it was found the number of times where a bird could be found in that same position (Figure 2). When diving by the number of matrix collected in the video a percentage was found.

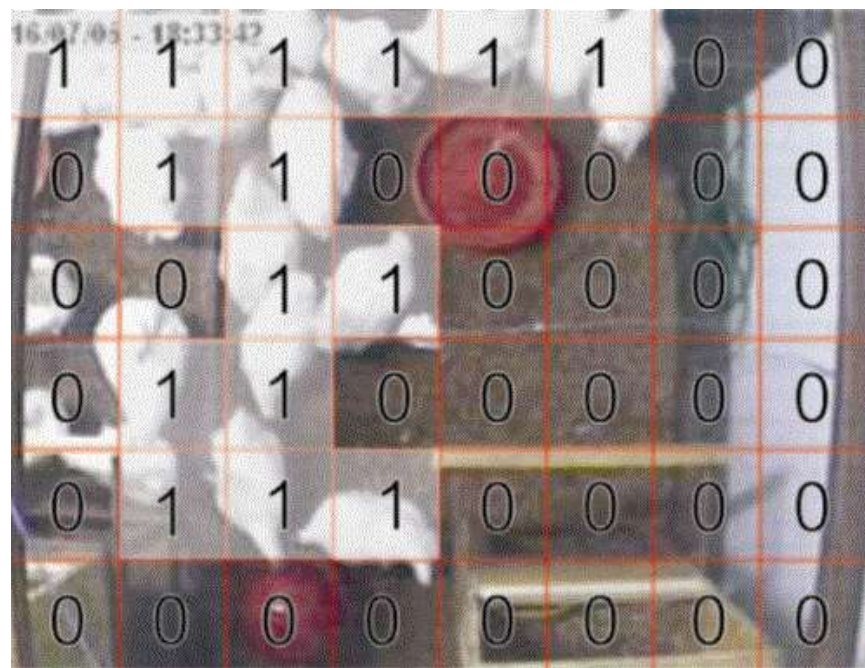

FIGURE 2. The image showing the grid and the adopted counting related to the occupancy of birds in an explicit area of the box.

Using this method it was possible to obtain the percentage of the chance of finding one bird in a certain spatial position, combined with a certain period of the day, and a certain dry bulb temperature, and at a certain behavioral pattern. With all combinations it was possible to visualize the profile of the birds cluster due to the change in the ambient rearing conditions (NÄ̈̈S et al., 2009), as well as a certain adopted behavioral pattern.

\section{RESULTS AND DISCUSSION}

The developed software was able to detect described behaviors, such as the opening of wings in a special software window (Figure 3a), and the enhanced image (Figure 3b). The following parameters 1) Background intensity (which help minimize the "noise" of images, such as the screen over the box); 2) Minimum area, and 3) Maximum area were adjusted in order to enhance the selected image. The images with bird which could represent some interest in the study were separated from the group. The previous observations were used to save the videos snapshots both with the regular video and the Blob Explorer, in a moment that the bird would express a studied behavior such as preening, opening wings, running, prostration, stretching and threatening.

Since most of the described behaviors (PEREIRA, 2005; PEREIRA et al., 2007b) were not present in the video footage, the search was for the following behaviors: opening wings (Figure 3) cluster together (Figure 4) and being separated (Figure 5). 


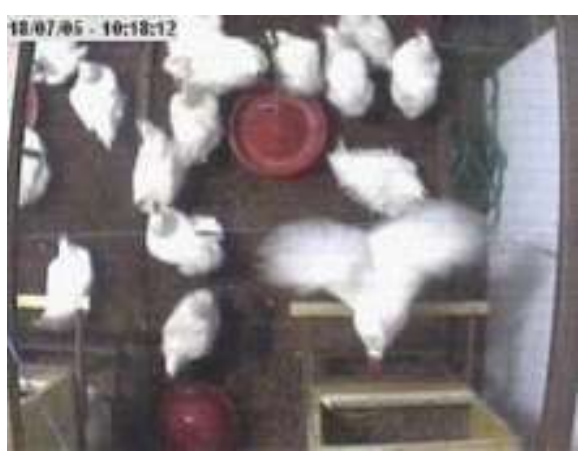

a

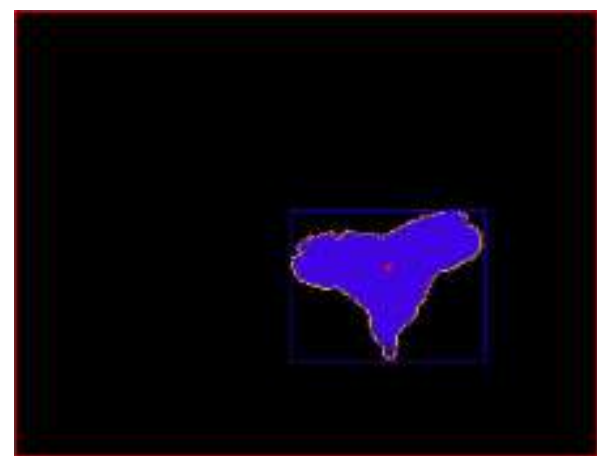

b

FIGURE 3. Video image related to the behavior of opening wings (a) and the result using the Blob Explorer filter (b).

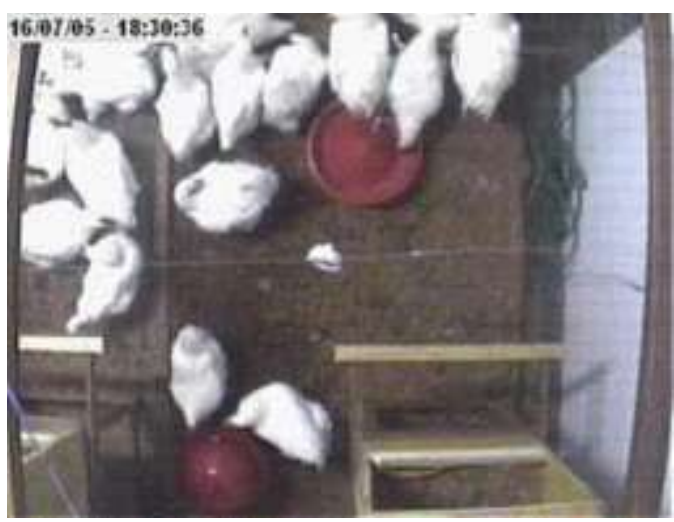

a

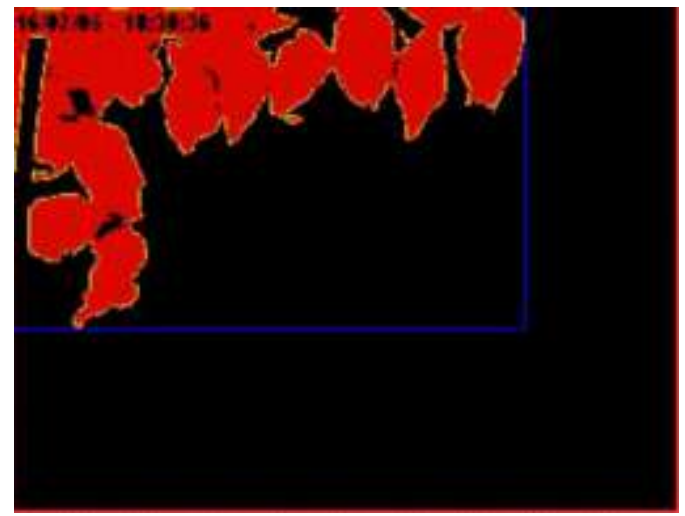

b

FIGURE 4. Video image related to the behavior of the birds clustering together (a) and the result using the Blob Explorer filter in a special selection of an area (b).

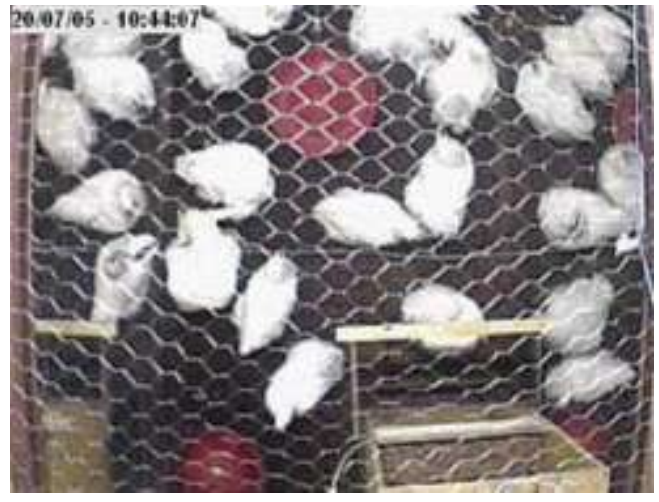

a

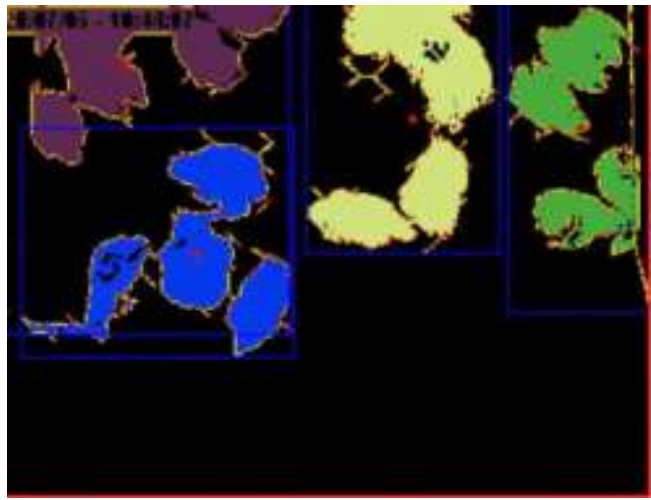

b

FIGURE 5. Video image related to the behavior of the birds being separated (a) and the result using the Blob Explorer filter in a special selection of an area (b).

The grid in each image (Figure 2) enhanced the way for registering the birds occupying a certain position in the box. PEREIRA (2005) recorded female broiler breeder data for 12 days during morning and afternoon (54 videos). For the purpose of this study, it was adopted the following ambient temperature variation: $\leq 29^{\circ} \mathrm{C}$ (within the upper limit of the thermal neutral zone threshold, as proposed by FRANCO-JIMENEZ et al., 2007), and $>29{ }^{\circ} \mathrm{C}$ (heat stress; SOLEIMANI et al., 2011). From the 54 videos, six videos by box were selected (a total of 18), where two of them were taken with the same ambient temperature, one was recorded in the morning and the other in the afternoon. The analysis is presented in Figure 6, where the shaded areas represent the places the birds were in effect occupying during the morning (Figure 6a) and the afternoon (Figure 6b). 


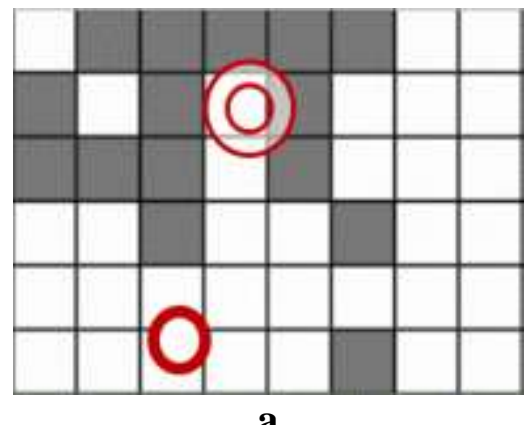

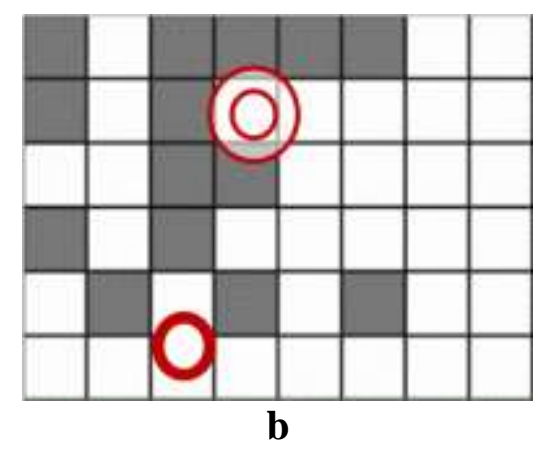

b

Double circle $=$ feeder; single circle $=$ drinker.

FIGURE 6. Area the birds occupied in the morning (a) and in the afternoon (b).

It was observed that, in the morning (Figure 6), the birds cluster close to the feeder waiting for the feedstuff (Figure 7). Chickens are animals with social behavior of clustering, and this may induce incorrect evaluation of explicit way of crowding inside a certain environment (FEBRER et al., 2006; BUIJS et al., 2010). However, as the ambient temperature increased birds stay away from each other in order to increase the sensible heat loss (FRANCO-JIMENEZ et al., 2007). The birds' distribution was proportional to the values of ambient temperature (SOLEIMANI et al., 2011) and related both to the period and feeding strategy.

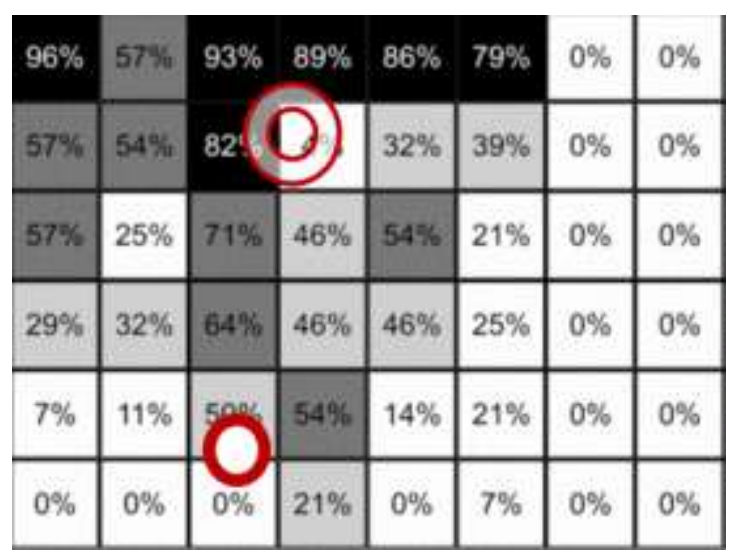

Double circle $=$ feeder; single circle $=$ drinker.

FIGURE 7. Percentage of occupation of floor area by the breeders, in the morning, prior to the feed distribution.

Data were computed from the areas where it was feasible to find a bird during the day, by the ambient temperatures $\leq 29$ and $>29^{\circ} \mathrm{C}$. At $29^{\circ} \mathrm{C}$ (Figure 8a) the breeders spent more time in the area of the feeder (the darker area of the graph), while during the exposition to extreme heat stress (Figure 8b) they spent more time in the area near the drinker.

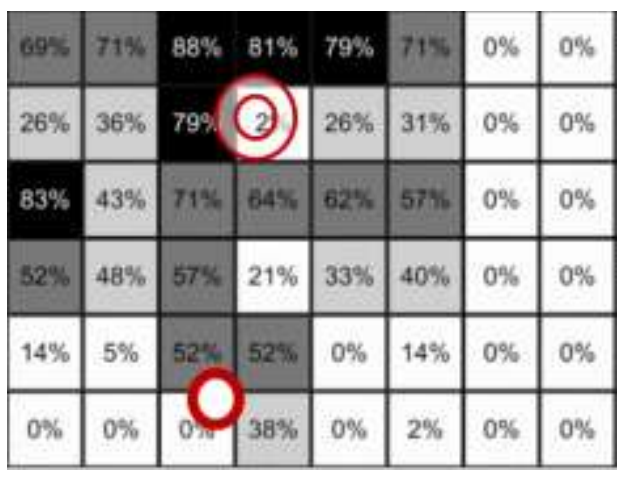

a

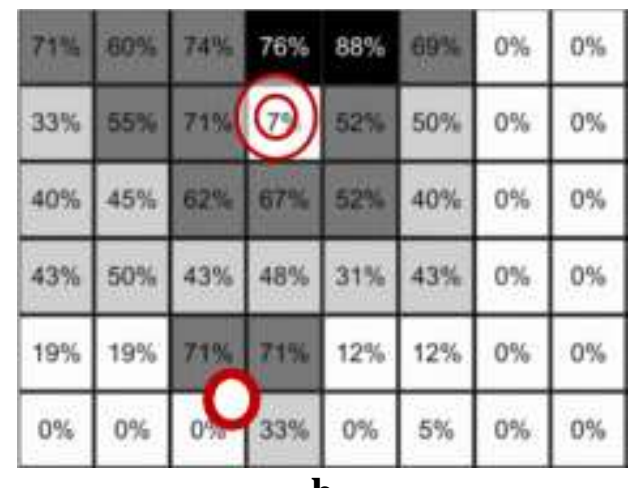

b

Double circle $=$ feeder; single circle $=$ drinker.

FIGURE 8. Distribution of the breeders at ambient temperature $\leq 29^{\circ} \mathrm{C}$ (a), and ambient temperature $>29^{\circ} \mathrm{C}(\mathrm{b})$. 
Breeders tend to access the drinker more often when temperatures are above the thermal neutral zone than when rearing temperatures are low (CURTO et al., 2007; SOLEIMANI et al., 2011). They behave like this either to drink the water or to benefit from the cooling effect of the water evaporation in the drinker's area. PEREIRA et al. (2007) found a positive association of drinking with temperature, indicating that when temperature increases, the birds remained at drinker longer.

There is a higher concentration of birds in different regions of the drinker and feeder on the thermal neutral environment. In these areas, the birds' behavior expressed as dust bathing, preening, scratching and laying down. All these behaviors lead to the welfare of birds. The behavior of a dust bathing and foraging, for instance, is due to the presence of suitable substrate (PETHERICK, 2006), favorable conditions of light and heat (DUNCAN, 1998) and social interactions (OLSSON et al., 2002). The behavior of a sand bath is intended to reduce parasites, and, therefore, has close relationship with the behavior of clean feathers (DUNCAN, 1998). The frustration of scratching behavior leads to negative indicator of feather pecking (HAAS et al., 2010) in an attempt to alleviate this frustration. NICOL et al. (2009) found that hens have a preference for environments where they are offered the opportunity to scratch and clean feathers. During hot ambient conditions, the behavior of the birds became more restricted in the regions of the feeder and the drinker.

When reared at high environment temperature the female breeder tend to prostrate to increase heat loss to the litter (FRANCO-JIMENEZ et al., 2007). Slightly above thermal neutral temperature the birds cluster around the feeder more often. It was possible to describe the following algorithm: Being $\mathrm{T}=$ rearing temperature, $\mathrm{F}=$ concentration of birds near the feeder, and $\mathrm{D}=$ concentration of birds near the drinker:

$$
\begin{aligned}
& \text { If } \mathrm{T} \geq 29^{\circ} \mathrm{C} \text { then } \mathrm{F}<50 \% \\
& \text { If } \mathrm{T}<29^{\circ} \mathrm{C} \text { then } \mathrm{D}<15 \%
\end{aligned}
$$

\section{CONCLUSIONS}

The methodology allowed the identification of the female broiler breeders clusters, as a response to changes in the environmental rearing conditions, and an algorithm was developed to describe their behavioral pattern.

\section{ACKNOWLEDGEMENTS}

The authors express their gratitude to FAPESP and CNPq for the research support.

\section{REFERENCES}

BUIJS, S.; KEELING, L.J.; TUYTTENS, F.A.M. Using motivation to feed as a way to assess the importance of space for broiler chickens. Animal Behaviour, Amsterdam, v.81, n.1, p.145-151, 2011.

BUIJS, S.; KEELING, L.J.; VANGESTEL, C.; BAERT, J.; VANGEYTE, J.; TUYTTENS, F.A.M. Resting or hiding? Why broiler chickens stay near walls and how density affects this. Applied Animal Behaviour Science, Amsterdam, v.124, n.3-4, p.97-103, 2010.

CANNELL, R.C.; BELK, K.E.; TATUM, J.D.; WISE, J.W.; CHAPMAN, P.L.; SCANGA, J.A.; SMITH, G.C. Online evaluation of a commercial video image analysis system (Computer Vision System) to predict beef carcass red meat yield and for augmenting the assignment of USDA yield grades. Journal of Animal Science, Maryland, v.80, n.3, p.1195-1201, 2002.

CURTO, F.P.F.; NÄÄS, I.A.; PEREIRA, D.F; SALGADO, D.D. Estimativa do padrão de preferência térmica de matrizes pesadas (frango de corte). Revista Brasileira de Engenharia Agrícola e Ambiental, Campina Grande, v.11, n.2, p.211-216, 2007. 
DUNCAN, I.J.H. Behavior and behavioral needs. Poultry Science, Maryland, v.77, n.3, p. 1766$1772,1998$.

FEBRER, K.; JONES, T.A.; DONNELLY, C.A.; DAWKINS, M.S. Forced to crowd or choosing to cluster? Spatial distribution indicates social attraction in broiler chickens. Animal Behavior, Washington, v.72, n.2, p.1291-1300, 2006.

FRANCO-JIMENEZ, D.J.; SCHEIDELER, S.E.; KITTOK, R.J.; BROWN-BRANDL, T.M.; ROBESON, L.R.; TAIRA, H.; BECK, M.M. Differential effects of heat stress in three strains of laying hens. Journal of Applied Poultry Research, Raleigh, v.16, n.2, p.628-634, 2007.

HAAS, E.N.; NIELSEN, B.L.; BUITENHUS, A.J.; RODENBURG, T.B. Selection on feather pecking affects response to novelty and foraging behavior in laying hens. Applied Animal Behavior Science, Amsterdam, v.124, n.1, p.90-96, 2010.

MCCLURE, E.K.; SCANGA, J.A.; BELK, K.E.; SMITH, G.C. Evaluation of the E+V video image analysis system as a predictor of pork carcass meat yield. Journal of Animal Science, Maryland, v.81, n.3, p.1193-1201, 2003.

MOLLAH, B. R.; HASAN, A.; SALAM, A.; A. ALI, A. Digital image analysis to estimate the live weight of broiler. Computers and Electronics in Agriculture, Washington, v.72, n.1, p.48-52, 2010.

MORROW-TESCH, J.; DAILEY, J. W.; JIANG, H. A video data base system for studying animal behavior. Journal of Animal Science, Maryland, v.76, n.1, p.2605-2608, 1998.

NÄÄS, I.A.; LAGANÁ, M.; MOLLO NETO, M. Estimating broiler breeder welfare using image analysis. In: WORLD CONGRESS OF COMPUTERS IN AGRICULTURE AND NATURAL RESOURCES, 7., 2009, Reno. Proceedings...St. Joseph: ASABE, 2009. 1 CD-ROM.

NICOL, C.J.; CAPLEN, G.; EDGAR, J.; BROWNE, W.J. Associations between welfare indicators and environmental choice in laying hens. Animal Behavior, Washington, v.78, n.1, p.413-424, 2009.

OLSSON, I.A.S.; DUNCAN, I.J.H.; KEELING, L.J.; WIDOWSKI, T.M. How important is social facilitation for dust bath in laying hens? Applied Animal Behavior Science, Amsterdam, v.79, n.2, p.285-297, 2002.

PEREIRA, D.F. Metodologia para estimativa de bem-estar de matrizes de frango de corte utilizando monitoramento digital e construção de modelos de simulação. 2005. $140 \mathrm{f}$. Tese (Doutorado em Construções Rurais e Ambiência) - Faculdade de Engenharia Agrícola, Universidade Estadual de Campinas, Campinas, 2005.

PEREIRA, D.F.; NÄÄS, I.A.; ROMANINI, C.E.B.; SALGADO, D.D.; PEREIRA, G.O.T. Broiler breeder behavior and egg production as function of environmental temperature. Brazilian Journal of Poultry Science, Campinas, v. 9, n.1, p.9-16, 2007a.

PEREIRA, D.F.; NÄÄS, I.A.; SALGADO, D.D.; GASPAR, C.R.I.V.; BIGHI, C.A.V.; PENHA, N.L.J.V. Correlations among behavior, performance and environment in broiler breeders using multivariate analysis. Revista Brasileira de Ciência Avícola, Campinas, v.9, n.4, p.207-213, 2007 b.

PETHERICK, J.C. Animal welfare provision for land-based livestock industries in Australia. Australian Veterinary Journal, Melbourne, v.84, n.2, p.379-383, 2006.

PRIETO M. T.; CAMPO, J.L. Effect of heat and several additives related to stress levels on fluctuating asymmetry, heterophil:lymphocyte ratio, and tonic immobility duration in White Leghorn chicks. Poultry Science, Raleigh, v.89, n.3, p.2071-2077, 2010.

SCHWARTZKOPF-GENSWEIN, K.S.; STOOKEY, J.M.; CROWE, T.G.; GENSWEIN, B.M.A. Comparison of image analysis, exertion force, and behavior measurements for use in the assessment of beef cattle responses to hot-iron and freeze branding. Journal of Animal Science, Maryland, v.76, n.2, p.972-979, 1998. 
SERGEANT, D.; BOYLE, R.; FORBES, M. Computer visual tracking of poultry. Computers and Electronics in Agriculture, Washington, v.21, p.1-18, 1998.

SOLEIMANI, A.F.; ZULKIFLI, I.; OMAR, A.R.; RAHA, A.R. Physiological responses of 3 chicken breeds to acute heat stress. Poultry Science, Raleigh, v.90, n.3, p.1435-1440, 2011.

YANAGI JR, T.; SILVA, E.; BRAGA JR., R.A.; LOPES, M. A.; DAMASCENO, F. A.V; SILVA, G.C. de A. E. Digital surface area assessment of broiler chickens. Engenharia Agrícola, Jaboticabal, v.33, n.3, p.468-476, 2011.

ZHANG, J.; GONG, S. People detection in low-resolution video with non-stationary background. Image and Vision Computing, Guildford, v.27, p.437-443, 2009. 